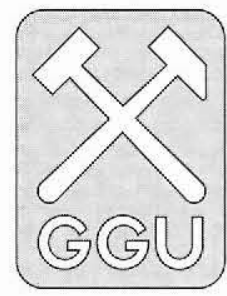

\title{
Large scale geochemical variation in the Precambrian of West and South Greenland
}

\author{
Agnete Steenfelt
}

Reconnaissance geochemical mapping by means of stream sediment and water has been carried out by the Geological Survey of Greenland (GGU) in West and South Greenland since 1979 (Steenfelt, 1987, 1993). The aim of the programme is to evaluate the potential for mineral resources. The geochemical data are used in two ways: (1) to identify chemical anomalies indicative of mineralisation; and (2) to contribute to the recognition of environments favourable to ore deposition. However, when compiled over large areas the data also permit a distinction to be made of large scale crustal domains.

In 1993 the coverage of the Precambrian terrain from Uummannaq to Kap Farvel was completed, and it will be possible to study distributions of c. 40 chemical elements along an almost $1200 \mathrm{~km}$ long segment of the Laurentian shield comprising an Archaean and two Proterozoic domains (Fig. 1; Kalsbeek, this report). The distribution of the elements potassium (K) and calcium (Ca) are presented here as examples to illustrate the geochemical variation over the shield (Fig. 2).

\section{Data acquisition}

The reconnaissance geochemical mapping programme is based on stream sediment and water collected at a density of one sample per 20 to $30 \mathrm{~km}^{2}$ in West Greenland and one sample per 5 to $6 \mathrm{~km}^{2}$ in South Greenland. Each stream sediment sample is a composite of 3 to 10 subsamples collected at different places in a stream bed along 10 to $50 \mathrm{~m}$ of its course. Samples are dried and sieved and the less than $0.1 \mathrm{~mm}$ grain size fraction is analysed.

The individual surveys involved in the coverage of West and South Greenland are shown in Figure 1. The sampling has had varying budgets and has often been tied to other GGU activities for logistical reasons, which explains the irregularity in size and location. Results from individual surveys of the geochemical programme are currently published in GGU's Open File Series and Thematic Map Series.

In the course of the geochemical mapping programme, the availability of analytical facilities has changed and as a result the samples have been analysed at a number of different laboratories (Risø National Laboratory and Geo-" logical Survey of Greenland, both in Denmark; Sveriges Geologiska AB, Sweden; and Bondar-Clegg and Activation Laboratories Ltd., both in Canada) using a number of analytical methods (delayed neutron counting for $\mathrm{U}$; various forms of X-ray fluorescence techniques for major

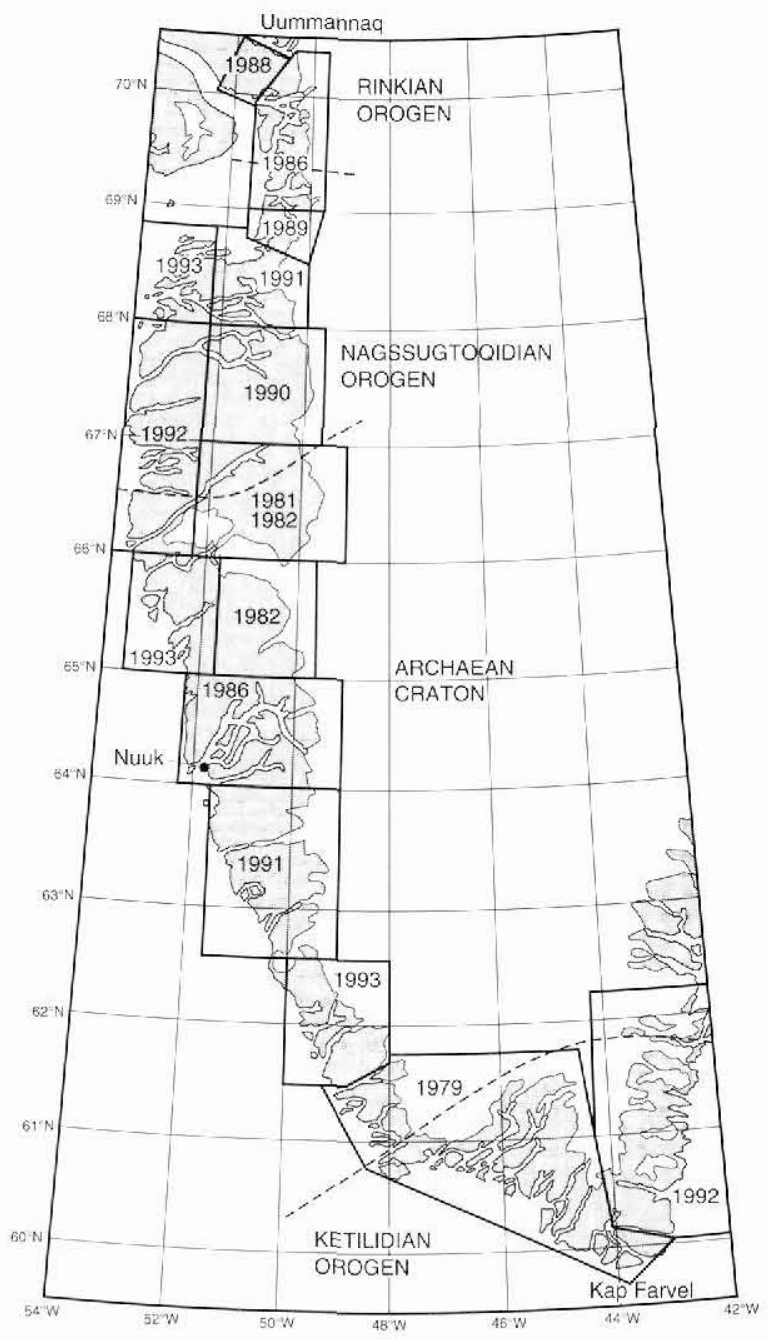

Fig. 1. Areal coverage and sampling year of reconnaissance geochemical surveys conducted in the Precambrian shield of West and South Greenland in the period 1979 to 1993. The boundaries of major tectonostratigraphical units are shown. 
and trace elements; atomic absorption spectrometry and instrumental neutron activation for a suite of major and trace elements). Samples from recent years have been analysed for a suite of c. 45 major and trace elements and older samples have been reanalysed when required to obtain the same suite of elements for all samples.

Due to analytical bias between laboratories and methods it has been necessary to calibrate all the different data sets before the preparation of geochemical element distribution maps of the entire area (Steenfelt, in press). A number of the elements exhibit distribution patterns which provide information about the crustal structure of this part of Greenland. The maps of $\mathrm{K}$ and $\mathrm{Ca}$ are shown as examples (Fig. 2) and they are discussed in the following.

\section{Discussion of potassium and calcium distribution}

The causes and mechanisms of crustal differentiation have been much discussed, but it is generally agreed that differentiation results in an increase in potassium and other lithophile elements at high crustal levels, and thus a relative increase in calcium and other elements at lower crustal levels (Table 1).

Stream sediment samples are composite samples of drainage basins, and in the course of the geochemical reconnaissance mapping programme it has been demonstrated that the stream sediment chemistry reflects the chemistry of the bedrock fairly closely (e.g. Steenfelt \& Kunzendorf, 1979; Steenfelt, 1988; Steenfelt et al., 1992). Regional scale lithogeochemical units and their boundaries are clearly distinguished in geochemical maps based on stream sediment in Greenland and elsewhere (e.g. Plant \& Moore, 1979; Steenfelt, 1990; Kerr \& Davenport, 1990). The main compositional change from bedrock to stream sediment in Greenland, is that the proportion of weathering resistant minerals such as amphiboles, garnets, and

Table 1. Estimates for the composition of upper and lower crust, upper and bulk Archaean crust (Taylor \& McLennan, 1985)

\begin{tabular}{lcccc}
\hline & Low. crust & Upp. crust & Upp. Arch. & Bulk Arch. \\
& $\%$ & $\%$ & $\%$ & $\%$ \\
\hline $\mathrm{SiO}_{2}$ & 54.4 & 66.0 & 60.1 & 57.0 \\
$\mathrm{TiO}_{2}$ & 1.0 & 0.5 & 0.8 & 1.0 \\
$\mathrm{Al}_{2} \mathrm{O}_{3}$ & 16.1 & 15.2 & 15.3 & 15.2 \\
$\mathrm{FeO}$ & 10.6 & 4.5 & 8.0 & 9.6 \\
$\mathrm{MgO}$ & 6.3 & 2.2 & 4.7 & 5.9 \\
$\mathrm{CaO}$ & 8.5 & 4.2 & 6.2 & 7.3 \\
$\mathrm{Na}_{2} \mathrm{O}$ & 2.8 & 3.9 & 3.3 & 3.0 \\
$\mathrm{~K}_{2} \mathrm{O}$ & 0.34 & 3.4 & 1.8 & 0.9 \\
\hline
\end{tabular}

accessory minerals (zircons, allanite etc.) increases in the stream sediment while the proportion of micas and feldspars decreases.

The variation in $\mathrm{K}$ and $\mathrm{Ca}$ concentrations displayed by the maps (Fig. 2,) is probably related to changes in the level of the exposed part of the crust. A high $\mathrm{K}$ concentration combined with low $\mathrm{Ca}$ concentration in an area is taken to indicate that the area represents a high crustal level which has never been subjected to granulite facies metamorphism. A lower crustal level would show low $\mathrm{K}$ and high $\mathrm{Ca}$ reflecting the predominance of granulite facies gneisses with plagioclase, hornblende and hypersthene. Local enrichment of $\mathrm{K}$ in an otherwise $\mathrm{K}$ poor area would indicate an uplift of a deep crustal level to a higher position, after which it was intruded by granitic or alkaline magma. Such events are often the result of ocean-continent or continent-continent collision. Local clusters of high $\mathrm{Ca}$ usually reflect occurrences of basaltic, amphibolitic or, locally, carbonatitic rocks in the gneiss terrain.

A thorough examination of the $\mathrm{K}$ and $\mathrm{Ca}$ data in relation to the known regional geology of the map area demonstrates the validity of this interpretation, and indicates that well defined boundaries between provinces of different crustal levels probably reflect terrane or plate boundaries (Steenfelt, in press).

Known terrane boundaries in the Godthåbsfjord area (e.g. McGregor et al., 1991) are reflected as distinct changes in the concentration levels of $\mathrm{K}$ and $\mathrm{Ca}$ (Fig. 2), and hence the similar change displayed at Nordre Strømfjord is interpreted to reflect the location of a terrane boundary which has not previously been recognised.

The Proterozoic Ketilidian orogen in South Greenland is clearly distinguished by high $\mathrm{K}$ and low Ca values. Rocks at high crustal level have been additionally enriched in $\mathrm{K}$ through mid-Proterozoic alkaline magmatism (Gardar Province, Upton \& Emeleus, 1987) and intrusion of rapakivi granites. Enrichments in $\mathrm{K}$ over the Archaean craton reflect the presence of the known granite complexes, Qôrqut and Ilivertalik, and also highlights the Neria granite which has not previously been recognised as a major granite intrusion (Steenfelt et al., 1994).

The two maps demonstrate that geochemical surface data compiled over large areas in Greenland can be used to distinguish and characterise structural elements of the Precambrian crust. Such information contributes to the recognition of plate tectonic settings which create favourable environments for ore deposition.

Fig. 2. Geochemical map of $\mathrm{K}_{2} \mathrm{O}$ and $\mathrm{CaO}$ calculated as volatilefree concentrations and corrected for analytical bias between individual surveys. The scaling of the dot size is chosen to emphasise the regional differences. 


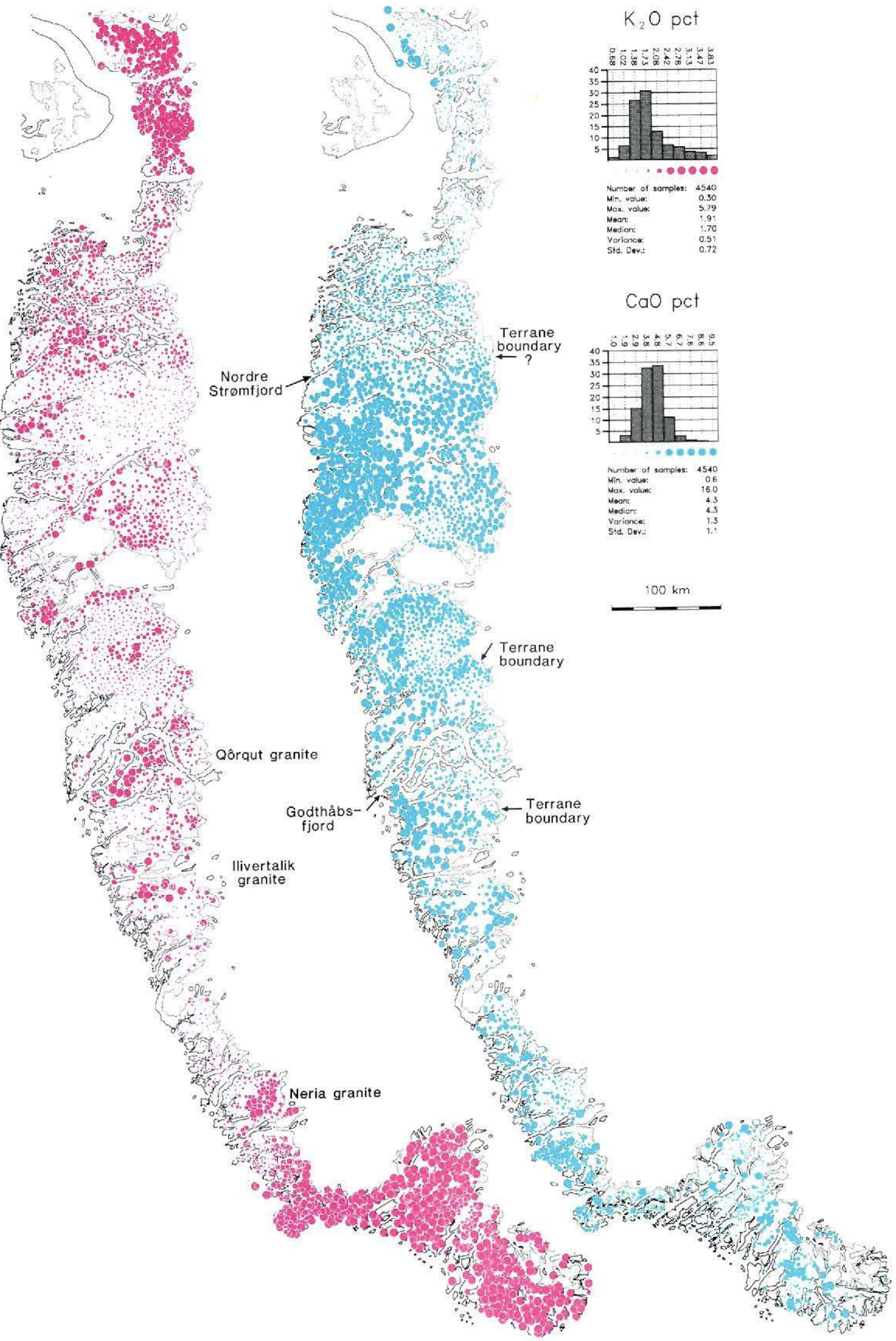


Acknowledgments. Thanks are due to the many persons, collectors, pilots and laboratory personnel, who have participated in GGU's reconnaissance geochemical mapping programme over the years. Special thanks are due to Else Dam who has been of invaluable assistance in all phases of the programme since 1981. The Mineral Resource Administration for Greenland supported the programme financially in 1992 and 1993.

\section{References}

Kerr, A. \& Davenport, P. H. 1990: Application of geochemical mapping techniques to a complex Precambrian shield area in Labrador, Canada. J. Geochem. Explor. 39, 225-247.

McGregor, V. R., Friend, C. R. L. \& Nutman, A. P. 1991: The late Archaean mobile belt through Godthåbsfjord, southern West Greenland: a continent-continent collision zone? Bull. geol. Soc. Denmark 39, 179-197.

Plant, J.A. \& Moore, P.J. 1979: Regional geochemical mapping and interpretation in Britain. Phil. Trans. R. Soc. London B288, 95-112.

Steenfelt, A. 1987: Geochemical mapping and prospecting in Greenland - a review of results and experience. J. Geochem. Explor: 29, 183-205.

Steenfelt, A. 1988: Progress in geochemical mapping of West Greenland. Rapp. Gronlands geol. Unders. 140, 17-24.

Steenfelt, A. 1990: Geochemical patterns related to major tectonostratigraphic units in the Precambrian of northern Scandinavia and Greenland. J. Geochem. Explor. 39, 35-48.
Steenfelt, A. 1993: Geochemical Mapping - Progress in Greenland. J. Geochem. Explor. 49, 5-13.

Steenfelt, A. in press: Crustal structure in West and South Greenland reflected by regional distribution patterns of $\mathrm{Ca}$ and $\mathrm{K}$ in stream sediment. Rapp. Gronlands geol. Unders.

Steenfelt, A. \& Kunzendorf, H. 1979: Geochemical methods in uranium exploration in northern East Greenland. In Watterson, J. R. \& Theobald, P. K. (ed.) Geochemical exploration 1978, 429-442. Rexdale, Ontario: Association of Exploration Geochemists.

Steenfelt, A., Dam, E. \& Nielsen, J. P. 1992: Reconnaissance geochemical exploration of map sheet $68 \mathrm{~V} 2\left(67^{\circ} 55^{\prime}\right.$ to $68^{\circ} 45^{\prime} \mathrm{N}$, $50^{\circ} 15^{\prime}$ to $\left.52^{\circ} 45^{\prime} \mathrm{W}\right)$, West Greenland. Open File Ser. Grønlands geol. Unders. 92/7, 14 pp.

Steenfelt, A., Dam, E. \& Petersen, A. 1994: Reconnaissance geochemical mapping of the Paamiut region $\left(61^{\circ} 25^{\prime}\right.$ to $62^{\circ} 45^{\prime} \mathrm{N}$, $48^{\circ} 00^{\prime}$ to $50^{\circ} 00^{\prime} \mathrm{W}$ ), South-West Greenland. Open File Ser. Gronlands geol. Unders. 94/1, 14 pp.

Taylor, S. R. \& McLennan, S. M. 1985: The continental crust: its composition and evolution, 312 pp. Oxford: Blackwell Scientific Publications.

Upton, B. G. J. \& Emeleus, C. H. 1987: Mid-Proterozoic magmatism in southern Greenland, the Gardar Province. In Fitton, J. G. \& Upton, B. G. J. (ed.) Alkaline igneous rocks. Spec. Publ. geol. Soc. Lond. 30, 449-471.

\section{A. S., Geological Survey of Greenland, Copenhagen}

